\title{
A COMPREENSÃO DA ILUSTRAÇÃO NA LITERATURA INFANTIL A PARTIR DO PENSAMENTO DE ROLAND BARTHES
}

\section{UNDERSTANDING ILLUSTRATION IN CHILDREN'S LITERATURE BASED ON ROLAND BARTHES'S THOUGHT}

\author{
Hélio Márcio Pajeúa \\ Rayanne Ferreira Alves Barbosa de Limab
}

\begin{abstract}
RESUMO
Introdução: A literatura infantil tem suas origens nos mitos orais, fábulas e contos de fadas, e a ilustração os acompanha desde o nascimento como um gênero literário. É necessário que o bibliotecário não restrinja sua ação apenas à disponibilização das obras infantis com imagens e textos a serem lidos pelas crianças, mas que também compreenda o processo de constituição e das relações ente imagem e texto no universo de narrativas do ilustrador e do autor, a fim de desenvolver melhores práticas de mediação entre a obra e o leitor. Objetivo: Assim, neste artigo, pretendemos discutir a importância da ilustração e o papel do ilustrador na literatura infantil, como forma de enfatizar a arquitetura de um diálogo entre as linguagens utilizadas no conjunto de narrativas que integram autor, ilustrador, trabalho e leitor. Metodologia: Realizou-se um levantamento de dados por meio de pesquisa bibliográfica exploratória e documental, analisados com base nos conceitos de relais e ancoragem, de Roland Barthes. Foram selecionadas obras de dois ilustradores residentes na Região Metropolitana do Recife, além de entrevistas com os mesmos. Resultados: Foram identificados os enunciados dados pelos ilustradores em suas obras, e foi observado como se dão os processos de interação e a constituição de sentidos conotativos e denotativos entre a imagem e o texto em obras de literatura infantil. Conclusões: A relação do texto e imagem se dá em pelo menos de três formas: o tipo de imagem que é empregada nos livros; o projeto gráfico que é utilizado para a confecção da parte física do livro; e o tipo de figura linguística, dentro da imagem, que será empregada em consonância ou não com a parte textual. Vai depender muito do estilo do ilustrador, do seu projeto enunciativo em relação ao texto do autor e da sua liberdade de criação dentro da obra.
\end{abstract}

\footnotetext{
a Doutor em Linguística pela Universidade Federal de São Carlos (UFSCar). Professor Adjunto do Departamento de Ciência da Informação da Universidade Federal de Pernambuco (UFPE). E-mail: heliopajeu@gmail.com

b Bacharela em Biblioteconomia pela Universidade Federal de Pernambuco. E-mail: djohar.ayanne@gmail.com
} 
Descritores: Literatura infantil. Mediação na biblioteca. Imagens. Linguagem.

\section{INTRODUÇÃO}

A história da literatura destinada ao público infantil é permeada por diversos fatores e construída sob a influência do comportamento da sociedade. Inicialmente, não existiam histórias voltadas às crianças, e as histórias contadas e lidas por elas, bem como tudo que consumiam, eram, na verdade, destinados ao público adulto, tais como as histórias de cavalarias, novelas, romances, etc. Com o passar do tempo, com a crescente circulação desse conteúdo, o comércio livreiro veio a enxergar na criança um potencial consumidor, e em virtude disso, começou a desenvolver, "produtos", revisando obras já existentes, mas com linguagens mais adequadas às faixas etárias.

Os livros infantis, surgiram no final do século XVII sendo isso possível devido a invenção da prensa por Gutemberg, que foi o precursor e responsável pela criação da tipografia, permitindo a impressão de conteúdos com mais agilidade, qualidade e precisão em seus textos. O advento da evolução tipográfica no processo de impressão no âmbito editorial permitiu a inserção de imagens de melhor qualidade nos livros e se tornou uma característica da literatura infantil.

De acordo com Freitas e Zimmermann (2008, p. 2)

à medida que novas técnicas de impressão surgem, como a água forte, a xilografia em cor, a litografia (1796) e a cromolitografia (1851), a ilustração ganha maior espaço dentro da área editorial. Outro importante invento do século XIX é a fotografia (1839) que, por seu realismo, fez com que ilustradores se voltassem mais ao estímulo à imaginação do que ao realismo.

Dessa forma, o livro infantil veio a se consolidar de fato com o surgimento dos contos de fadas escrito por Charles Perrault, autor das obras Chapeuzinho Vermelho, Cinderela, dentre outros. "É após o sucesso das obras de Perrault que a literatura infantil adquire espaço, caracterizada principalmente pelos contos de fadas". (ZIMMERMANN, RAMALHO; OLIVEIRA, 2007, p. 3). Assim, Perrault, arquiteta histórias para as crianças originárias dos conceitos populares, nas quais conta o desenrolar da sorte de personagens da classe baixa daquela época, sendo essas histórias moralizadoras e educativas. Uma das obras de 
renome do escritor Charles Perrault, Chapeuzinho Vermelho, tem a assinatura de Gustave Doré (1832-1883) nas ilustrações. A técnica artística predominante em seus desenhos são xilogravuras, "a mais antiga técnica de gravura, obtida a partir de desenho realizado em uma prancha de madeira, ferida em sulcos que projetam a imagem em relevo, depois embebida em tinta e reproduzida no papel" (RAMOS, 2013, p. 18).

A literatura infantil teve, portanto, a sua origem nos mitos orais, nas fábulas e nos contos de fadas, e a ilustração a acompanha desde o seu nascimento enquanto gênero literário. Deste modo, esse trabalho pretende discutir a importância da ilustração na literatura infantil, como forma de ressaltar a estima desse artifício artístico na integração entre leitor e obra e na dialogicidade entre texto e imagem que arquitetam o processo de constituição de sentidos do conjunto de narrativas no qual o livro infantil se insere.

Um livro ilustrado, seja infantil ou não, no plano da linguagem é composto por pelo menos três sistemas narrativos que se entretêm, quais sejam: a) o texto propriamente dito (sua forma, seu estilo, seu tom, suas imagens, seus motivos e temas); b) as ilustrações (seu suporte: desenho, colagem, fotografia, pintura e também, em cada caso, sua forma, seu estilo e seu tom); e c) o projeto gráfico, isto é, a capa, a diagramação do texto, a disposição das ilustrações, a tipologia escolhida, o formato e o tipo de papel) (AZEVEDO, 1998, p.3).

Desse modo, o livro infantil deve ocupar um lugar de mais consideração nos estudos da leitura, por se tratar de obras que são produzidas sob um viés educativo, mas também com o intuito recreativo e que mesclam diferentes linguagens. Em se tratando desse gênero, a imagem é um elemento de alta importância que contribui não somente no auxílio à compreensão do texto, como também torna a leitura mais prazerosa para o leitor iniciante. $E$ pelo fato da imagem ser um meio pelo qual há a representação de informações, é que cremos que o ilustrador e a ilustração tenham grande seriedade no processo de desenvolvimento comunicativo e aprendizado da leitura.

A Ciência da Informação, sobretudo a Biblioteconomia, se mostra desprovida de estudos acerca da análise desse tipo de conteúdo imagético, buscando a compreensão da imagem no seu sentido interpretativo e 
comunicacional, uma vez que se volta quase unicamente à analise textual e ao tratamento, organização e disseminação da informação de modo geral. Daí surge nossa proposta de averiguar o papel da imagem dentro do livro como fator preponderante à compressão textual. Nosso objetivo, portanto, é discutir a relação entre as imagens utilizadas nos livros infantis em diálogo com a parte textual da obra, tendo por base teorias dos estudos da linguagem, especificamente, a partir dos conceitos de ancoragem e relais de Roland Barthes.

Consideramos essa proposta pertinente, sobretudo na especificidade da Biblioteconomia, uma vez que a ela cabe formar profissionais que atuarão como mediadores da cultura e da informação. Nessa esfera, a literatura ganha espaço e mostra que a ilustração de obras infantis permeia uma fase muito importante na formação leitora, na alfabetização, momento em que as obras literárias infantis auxiliam na constituição da formação da personalidade, nas características de comportamento, psicologia e valores no ser humano. Assim, é necessário que o bibliotecário não restrinja sua ação de mediador apenas à disponibilização das obras infantis com imagens e textos que serão lidos pelas crianças, mas também que compreenda o processo de constituição e das relações ente imagem e texto no universo de narrativas construído por um profissional ilustrador e um autor, a fim de procurar desenvolver melhores práticas de mediação entre a obra e o leitor.

Para tanto, analisaremos, comparativamente, as obras de dois ilustradores residentes na Região Metropolitana do Recife, quais sejam: "Galinha sem ovo na boca do povo" de Cristiane Quintas, publicada em 2007 com ilustrações de Emerson Pontes ${ }^{1}$ e "A Casa Rosa" de Silvana Pinheiro Taets, publicada em 2004 e ilustrada por Rosinha². Nosso enfoque também será

\footnotetext{
${ }^{1}$ Emerson Nascido em Abreu e Lima é Artista plástico, formado pela Universidade Federal de Pernambuco e feliz da vida! À frente do Lugar-delícia Ateliê, um cantinho especial para criação de aquarelas e tantos outros desenhos. (Texto extraído do blog pessoal do autor-adaptado).

${ }^{2}$ Rosinha Nasceu em Recife e atualmente mora em Olinda, Pernambuco. Formou-se em Arquitetura, pela Universidade Federal de Pernambuco, mas depois de se apaixonar pela literatura infantil e juvenil. Conta: "- fechei o escritório e passei a me dedicar à ilustração. Em 1994 lancei meu primeiro livro, Som Coração. Fiz pós-graduação em Literatura Infantil e Juvenil na Faculdade de Filosofia do Recife e formação artística com o artista plástico japonês Sunish Yamada. Fui votante da FNLIJ durante sete anos e desde 1998 trabalho com formação de
} 
compreender o processo criativo do ilustrador na construção de imagens que possibilitem o auxílio na interpretação textual, e a partir disso abre espaços para inúmeras outras narrativas e interpretações em que o leitor pode construir se for do seu desejo. Azevedo (1998, p. 7) afirma que

\begin{abstract}
diante do texto literário, construído através da ficção e da linguagem poética, cada um de nós pode ter uma leitura, um sentimento e uma interpretação. Imagine, agora, ilustrá-los. As imagens, tal como o texto também sairão necessariamente creio eu, marcadas pela subjetividade, pela ambiguidade, pela plurissignificação, pelo enfoque poético e pela linguagem metafórica.
\end{abstract}

Destarte, o trabalho do ilustrador é trazer para o leitor essa infinidade de possibilidades de sentidos, como também possibilitando a criatividade por parte de quem ler. Sendo assim, o problema para esta pesquisa além de entender a relação texto e imagem nos livros infantis, procura refletir como o ilustrador, sendo o produtor de informação em texto literário infantil, enxerga o processo de criação das imagens que complementa a parte textual do livro, possibilitando assim a relação texto e imagem.

Esta importância dada ao ilustrador se deve ao fato de ele cumprir um papel fundamental no desenvolvimento interpretativo, cognitivo e intelectual que suas obras podem trazer para as crianças. Segundo afirma Spengler (1952, p. 42) "a literatura infantil passou a assumir uma função sociocultural, sensibilizando o seu leitor de forma lúdica e oferecendo diferentes maneiras de ver o mundo". Nisso o trabalho do ilustrador pode funcionar como um espelho a partir das suas obras pelas quais há a possibilidade de refletir e refratar situações cotidianas semelhantes à realidade das crianças, possibilitando afinidade entre a história e a vida pessoal de cada leitor.

Como caminho metodológico, foi utilizado levantamento de dados através da pesquisa exploratória de cunho bibliográfico. Também foi feita uma entrevista dirigida com os dois ilustradores supracitados, para um maior esclarecimento sobre como se dá, inicialmente, o processo criativo por parte desse profissional, sobre o planejamento da montagem dos elementos imagéticos, como é feita a

leitores. Em 2007 lancei Esmeralda, meu primeiro livro onde assino o texto e a ilustração." (Texto extraído website do autor- adaptado). 
sequência narrativa de imagens e como ele se enxerga nesse processo de ilustração das obras escolhidas. Com isso, cotejamos, em nossas análises, as obras com as declarações dos ilustradores nas entrevistas realizadas, tendo por base os estudos feitos sobre a imagem em publicidades desenvolvidos por Roland Barthes, para observar como se dão os processos de interação e constituição de sentidos entre a imagem e o texto aplicados em obras de literatura infantil.

\section{A ILUSTRAÇÃO COMO LINGUAGEM E PRINCÍPIO PARA A COMPREENSÃO DAS NARRATIVAS}

A comunicação, atualmente, se configura como uma das atividades mais importantes no orbe das relações humanas. Ela é vital, assim como andar, comer, agasalhar-se em dias de frio, ou refrescar-se nos dias quentes. Trata-se de uma atividade inerentemente humana que passou por diversas etapas em seu surgimento, desenvolvimento e maturação até chegar ao que conhecemos hoje com o suporte da tecnologia. Inicialmente, segundo Martelotta (2008) e Wilson Martins (2002) o processo comunicativo se deu de forma lenta, e sendo inexoravelmente inerente ao comportamento humano, o homem na sua necessidade de se comunicar buscou dentre os diversos meios que tinha para realizar este fim.

A comunicação se faz presente em nossas vidas de diversas formas seja por meio da fala, da escrita, de imagens. É válido ressaltar que antes mesmo da linguagem ser a linguagem que conhecemos, ela era antes muito mais gestual do que sonora, como afirma Volochínov (2013, p. 136) que "obviamente, em seus primeiríssimos estágios, ela não se parecia com nenhuma das línguas contemporâneas, nem com outras mais antigas." Acerca disso, sabe-se que os homens primitivos utilizavam, para se comunicar, gestos e pequenos sons feitos com a boca e que esse modo de comunicação durou por um longo período dando origem ao que conhecemos como linguagem. O estudioso alemão Ludwig Noiret afirma que [...] "a linguagem e a vida do intelecto nascem da atividade conjunta dirigida por um objetivo comum, do trabalho primitivo de nossos antepassados." (VOLOCHÍNOV, 2013, p. 136). 
Martins (2002, p.17) compreende que a linguagem, por mais absurdo que pareça, é que vai permitir a invenção da mão: na mão e na linguagem está contida toda a história do homem, pois há uma relação muito próxima entre o sentir do tato, com a relação da fala, e os demais sentidos. Nesse aspecto, a profunda relação do tato com o ato comunicativo é muito presente na atualidade, e um exemplo disso são os desenhos feitos pelos ilustradores.

A abstração desenvolvida pelo homem no ato comunicativo possibilitou 0 reconhecimento e a atribuição dos sentidos as coisas, de diferenciá-las, de discernir, de agrupar, segregar e assim por diante. Essa capacidade nos demonstra o quanto o ser humano sempre foi capaz de raciocinar em um nível a mais do que os outros animais, pois o fato de poder desenvolver o hábito de andar sob as 'patas' traseiras permitiu a liberdade nas 'patas' dianteiras, possibilitando o manuseio de objetos: de segurá-los, de senti-los com as mãos. "É que a mão começou a sentir os objetos quando os primeiros nomes começaram a lhes dar uma existência, se não autônoma, pelo menos desligável do conjunto indistinto em que antes disso se perdiam" (MARTINS, 2002, p.17).

Isso nos faz perceber que o pensamento, enquanto algo inerente ao ser, é indissociável da expressão verbalizada, visto que um depende do outro para existir. É a partir dessa reflexão que é possível abranger até onde vai a nossa consciência, nossa capacidade de abstração, criação e interpretação, pois 0 processo reflexivo toma forma na linguagem e é a linguagem que pode nos apresentar diversos caminhos a serem seguidos, em termos de abstração e reflexão. Logo, se abstraio, reflito, compreendo, produzo sentidos.

Assim, "a linguística tem como objeto de estudo a linguagem humana através da observação de sua manifestação oral ou escrita (ou gestual, no caso da língua dos sinais). Seu objetivo final é depreender os princípios fundamentais que regem essa capacidade exclusivamente humana de expressão por meio de línguas" (CUNHA; COSTA; MARTELOTA, 2008, p. 21). O desenvolvimento da linguagem permitiu $o$ aparecimento dos sistemas de línguas que se assemelham ao que conhecemos como sistemas escritos. E a partir disso, o sistema escrito sendo reconhecido como forma de comunicação pela linguística, constitui participação ativa no desenvolvimento da comunicação do ser humano através 
também das imagens e estas estão presentes em toda história da humanidade, desde as pinturas etruscas aos quadrinhos atuais.

A prática de associar pequenas imagens a textos escritos surgiu na Idade Média em que nos mosteiros, os monges copistas, além de cuidarem da transcrição da escrita das obras religiosas, também davam a beleza a esses livros incluindo iluminuras e miniaturas de desenhos, o que diríamos ser 0 princípio da ilustração nos livros. Ambas possuíam a função de ornamentar a caligrafia, entretanto, a primeira é considerada a mais importante pela sua ornamentação e uso de uma gama maior de cores. Segundo Martins (2002, p. 102),

Paul Dupont acreditava que a arte de ilustração dos livros viesse dos romanos, entre os quais o luxo dos manuscritos com letras doiradas sobre velino teria sido introduzido no começo do século III; Rouveyre, entretanto, assinala que já os papiros eram coloridos e que os pergaminhos gregos e romanos vinham com frequência enriquecidos de vinhetas e algumas vezes de desenhos no próprio texto.

Pode-se observar o caráter que era empregado nas ilustrações nesse período, que não tinham o papel somente de ilustrar, mas também de realizar fins decorativos. É também interessante observar como esses princípios foram mudando no decorrer do tempo e como eles chegaram até a atualidade como símbolos de expressões artísticas ou para fins comunicativos. $\mathrm{O}$ uso da imagem nos livros, seja qual gênero for, passou por diversos momentos de rejeição e repúdio, como se sabe que aconteceu nas obras infantis. Para Contrera e Hattori (2003, p. 56) a imagem é um termo que comumente é utilizado para designar representações gráficas ou verbais de algo que existe ou poderia existir. Em outras palavras, é a representação de algo por semelhança.

A profissão de ilustrador é importante para as obras infantis no sentido de que as idades iniciais necessitam desse conteúdo para enriquecer a sua visão de mundo e aprender mais com as obras e, consequentemente, desenvolver senso crítico a sua volta em relação às artes e as imagens. Pois como corrobora Alberton (2010, p. 21-2), "as ilustrações dos livros de Literatura Infantil usadas em atividades lúdicas auxiliam no desenvolvimento do ser humano durante a infância. Seus temas diferenciados possibilitam à criança estruturar um enredo, ajudando-a na sua inteligência emocional e intelectual como fonte de 
divertimento e saber, como um estímulo a imaginação".

A condição de análise do conteúdo do escritor é de total responsabilidade do ilustrador, pois este, encarregado do papel de transformar o que é texto em conteúdo imagético, dando suporte à parte escrita, participa da criação particular de cada indivíduo ao ler a obra. Há pouco tempo, deu-se o início da discussão sobre a relação texto e imagem, e a isso se atrela grande importância, pois na medida em que o texto omite um fato, a imagem deve entrar em ação para suprir aquela falta, ou em outros casos, criar um novo sentido para aquela situação, em que na parte textual não foi descrita com tanta abertura. O profissional tem e deve ter a liberdade de criar e dar vida à parte textual, posto que a ilustração é essencial para a compreensão, interpretação e leitura da obra. A esse respeito Zimmermann, (2008, p.5) destaca que

\begin{abstract}
no exercício de "letramento visual' as ilustrações dos livros infantis podem ser empregadas como importantes recursos e estímulos à sua aprendizagem, entre outros motivos por permitir uma observação pausada de seu leitor. Cabe a ele determinar o "seu tempo" de atenção e reflexão de cada ilustração e todo e qualquer elemento que compõe uma imagem, fugindo da velocidade, fugacidade e superficialidade das informações em outras mídias, como por exemplo, a televisão. Além disso, o livro possibilita o retorno a qualquer uma das páginas, ou a todas elas, quantas vezes for desejado com extrema facilidade, permitindo ao leitor estabelecer diferentes relações dentro de uma mesma história.
\end{abstract}

Uma das características do livro é a marcação do tempo, pela qual o leitor tem a possibilidade de contemplação que desejar da obra, podendo criar situações, sonhar com o que é lido e assim interpretar a obra a seu modo. A ilustração passa por vários momentos, e não se pode perder de vista que se trata de um recurso linguístico, da mesma forma como acontece com a oralidade e a escrita. Histórias que se utilizam de recursos de linguagem são bem mais elaboradas e requerem do leitor um olhar atento e aguçado. Portanto, lidar com imagens, lê-las com competência, perceber seus recursos e nuances faz parte do processo de apreensão, leitura e compreensão do mundo e de nossa própria existência (FONSECA, 2006, p.1).

É pertinente, pois a possibilidade de apreensão é indescritível, e ela vai além do que o ilustrador quer realmente passar em seu projeto discursivo, e a criança ou leitor de modo geral é livre para fazer esse tipo de apreensão da obra. 
Sendo assim

nos livros, as ilustrações podem exercer em relação ao texto verbal diferentes funções. Tanto podem ratificar os significados do texto, quanto antecipar, ampliar, extrapolar ou sugerir. No entanto, devemos cuidar para que nossas analogias não reproduzam um modelo de leitura de textos verbais. Temos diante de nós, um diálogo intenso a ser compreendido e discutido pelos leitores, que agora devem acrescentar às suas estratégias de leitura do texto verbal competências específicas que 0 auxiliem na compreensão do texto não-verbal, sem transpor modelos previamente prontos. (FONSECA, 2006, p. 34)

Nesse sentido, a imagem e o texto são linguagens que, entrelaçadas, arquitetam um importante processo constituição de sentido para a compreensão das narrativas na literatura infantil a partir da ilustração, e nesse artigo, procuremos compreender essas relações a partir do pensamento de Roland Barthes.

\section{OS PRINCÍPIOS DE RELAIS E ANCORAGEM DE ROLAND BARTHES NOS ESTUDOS IMAGÉTICOS}

Nascido na França no ano de 1915, Roland Barthes dedicou sua vida ao estudo dos signos e da semiologia. Seu estudo voltou-se à análise de imagens publicitárias, pois ele acreditava que a imagem representada nessa esfera podia significar mais do que ela aparentava ser. Visto isso, iniciou sua vida nos estudos imagéticos e teve seu livro publicado, postumamente: "A câmara clara" (1984), no qual discute sua análise sobre o estudo de imagens fotográficas.

Neste artigo, buscamos compreender os princípios utilizados por Barthes ao analisar suas imagens publicitárias no texto "Retórica da imagem" (1990), aplicados na ilustração de literatura infantil, mesmo se tratando de orbes distintos. Joly (2003, p. 50) esclarece que o objetivo de Barthes era o de pesquisar

se a imagem contém signos e quais seriam esses signos. Para isso, o pesquisador estabeleceu sua própria metodologia, que consistia [...] em postular que os signos a serem encontrados têm a mesma estrutura que a do signo linguístico, proposta por Saussure: um significante e um significado.

Em seu estudo, Barthes apregoa três possibilidades principais que 
envolvem as funções linguísticas a partir das quais se pode compreender a imagem, são elas: o sentido denotativo, o conotativo e o próprio elemento simbólico. É sabido que uma vez a imagem se configurando como polissêmica, isto é, ela possui mais de uma interpretação ou significado, cria-se uma cadeia de sentidos "podendo o leitor escolher alguns e ignorar outros" (BARTHES, 1990, p.32). E no momento de ler a imagem junto com o texto, podemos nos deparar com três mensagens, sendo estas: a primeira mensagem: linguística, podendo esta ser conotativa ou denotativa, a segunda mensagem: icônica, geralmente conotativa e a terceira mensagem: simbólica sendo sempre conotativa.

Nessa esteira de pensamento, Almeida Junior (2009, p. 137), considera que a

imagem revela imediatamente uma primeira mensagem, cuja substância é linguística: são legendas e etiquetas inseridas no natural da cena. [...] seguindo-se a esta mensagem linguística, há uma segunda mensagem de natureza icônica, o que caracteriza 0 entendimento da denotação. Já a terceira mensagem seria a simbólica trabalhando o campo da conotação (ALMEIDA JUNIOR, 2009, p.137).

Para Barthes, as relações que podemos encontrar no que diz respeito a mensagem linguística e a mensagem icônica são de ancoragem (fixação) e relais (revezamento). Ancoragem ou fixação corresponde ao fato do texto descrever e prender o sentido da imagem, não permitindo outra interpretação: cria uma cadeia cíclica constante de sentidos. Isso é possível devido à inclusão do texto juntamente com a imagem. Ele, ao reconhecer os multíplices meios de produção e usos da imagem, reflete que

é evidente que, fora da publicidade, a fixação pode ser ideológica, e esta é, sem dúvida, sua função principal; o texto conduz o leitor por entre os significados da imagem, fazendo com que desvie de alguns e assimile outros [...] [Logo], a fixação é um controle, detém uma responsabilidade sobre o uso da mensagem, frente ao poder de projeção das ilustrações; o texto tem um valor repressivo (BARTHES, 1990, p. 33).

Já o relais, ou o revezamento, corresponde a complementaridade entre texto e imagem, como no exemplo de charges e quadrinhos. Deste modo, nessa concepção

A palavra (na maioria das vezes é um trecho de diálogo) e a imagem têm uma relação de complementaridade; as palavras são, então, fragmentos de um sintagma mais geral, assim como 
as imagens e a unidade da mensagem é feita em um nível superior: o da história, o da anedota, o da diegese (BARTHES, 1990, p. 34).

Desta forma, o relais é importante no caso das imagens em movimento, como no cinema, não tanto pelas imagens, mas pelos diálogos que ocorrem e que permitem que as cenas avancem colocando em sequência as mensagens que não contém na imagem. Enquanto nos livros infantis, no caso das ilustrações, possuem uma mensagem codificada, fato de representar uma cena por meio de desenhos e há, ainda, os conceitos históricos que envolvem os desenhos como: perspectiva, composição, luz e sombra e outros, e por último, não existe uma origem para as cópias dos desenhos, eles simplesmente cabem em si. Dentro deste processo de codificação cabe a quem estuda decodificar ou não as situações representadas.

Como segue a explicação de Almeida Junior (2009, p. 139) "em Barthes, então, numa imagem, a primeira mensagem é linguística, que vem contribuir com a exposição de uma sequencialidade, um direcionamento de leitura, atenuando, assim, uma possível dispersão de entendimento."

A literatura infantil, recoberta de textos e imagens apresenta todos esses tipos de mensagens. A ilustração dos livros infantis, principalmente os só de imagem, possibilitam e muito esta amplitude de interpretações e criações de vários sentidos para a situação ali representada. Por isso, a tentativa mobilizar a teoria de Barthes em conjunto com as respostas que os ilustradores Emerson e Rosinha deram, não somente sobre a produção da parte artística, mas o que eles pensam e acham sobre a relação da imagem com o texto nos livros infantis, e de que forma isso influencia na interpretação da criança ou do leitor de modo geral.

\subsection{As Relações entre Texto e Imagem na Ilustração de Emerson Pontes e ROSINHA}

Emerson Pontes reside na cidade do Recife e trabalha com ilustrações desde 2005. Sua primeira obra como ilustrador foi o livro "Cururu Cururinho"; no entanto, a obra escolhida para compreender a nossa análise foi "Galinha sem 
ovo na boca do povo", escrita por Cristiane Quintas e publicada em 2007 pela editora Prazer de Ler, da cidade do Recife.

As obras ilustradas por Emerson, em sua maioria, são elaboradas com tinta nanquim sobre papel especial de algodão e colorido com tinta aquarela, sendo essa técnica de pintura sua maior marca. O desenvolvimento dos seus personagens se dá de forma mais solta e despojada, algo próximo de caricaturas. O próprio autor, revelou esse fato durante a entrevista realizada, ao enunciar que suas obras

têm algo caricato sim. Até porque tem essa relação com o que é a história. A história é para cima, é algo despojado e aí isso também me chama a atenção. $E$ aí é interessante que o desenho chegue a altura disso. Eu sei que são os primeiros, os primeiros eu tinha essa coisa de fazer os olhos bem redondos mesmo, de deixar algo bem expressivo (PONTES, 2017).

$E$ isso acompanha não somente o seu trabalho com a forma pela qual ele enxerga a vida também. Em se tratando de escolha dos textos para ilustrar, ele se diz muito atraído por obras com narrativas mais simples, com as quais ele se identifica, como é o caso da obra escolhida.

A obra "Galinha sem ovo na boca do povo" conta, de forma poética repleta de rimas, a situação de desespero pela qual a personagem, a galinha Zinha, passa ao descobrir que não consegue mais pôr ovos, e o seu destino então seria a panela. Ao descobrir isso, ela, imediatamente, foge do galinheiro. No momento de solidão, sem saber mais o que fazer, acaba por encontrar com sua amiga, a Pata Malvina, que lhe dá de presente um ovo seu; ovo de pato, dizendo que a amiga deveria chocar e criar o patinho, pois dali sairia um filho seu. Zinha se alegra e faz o que a sua amiga sugere: voltar ao galinheiro e chocar o seu ovo de pata.

Ao começar a análise pela capa do livro, é perceptível a noção da relação tanto do título do livro com a imagem que a ilustra, na qual há a galinha em cima do ninho, com uma expressão apreensiva ao olhar para o mesmo e não ver nada ali, ovo nenhum. Pode-se depreender que algo está para acontecer, pela expressão materializada na face da personagem. A cor da galinha Zinha, por ser roxa, demonstra que ela é a que possui uma cor diferente dos demais animais que aparecem no decorrer da narrativa. 
Figura 1 - Capa do livro Galinha sem ovo, na boca do povo (2007)

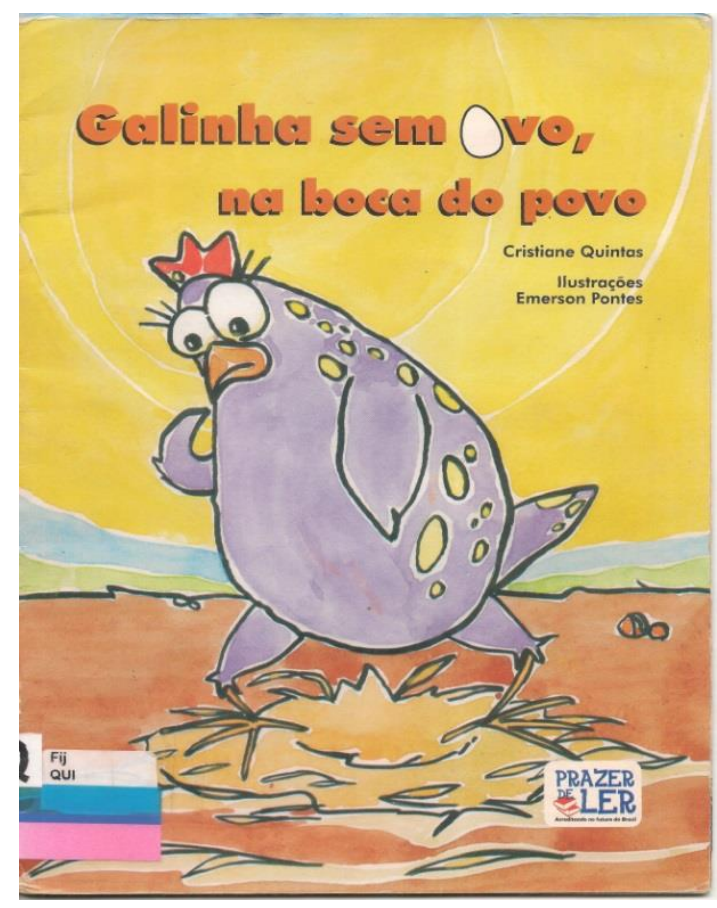

Fonte: Quintas, 2007.

Emerson alimenta uma forte relação com as cores, isso se deve ao seu estudo do círculo cromático: como ele mesmo diz: "Eu sempre fui fã dessa coisa do disco cromático e sempre fiz estudo de psicodinâmica de cor" (PONTES, 2017). No decorrer da história, começa a se tornar claro, um pouco dos motivos de Zinha ser dessa cor diferente, e isso é um elemento significante e forte para compreensão da história. Logo, a imagem de abertura do livro, representa o significante, postulado por Barthes, como citado anteriormente, o relais. Há a presença de cores quentes como o ocre da palha significando o ninho e 0 marrom, representando a terra e o calor do galinheiro; isso se demonstra mais presente no decorrer do livro, e é percebido que a história se constrói em dois momentos; o primeiro marcado pelo transcorrer da história dentro do galinheiro e depois na fuga de Zinha, quando ela encontra sua amiga Pata Malvina, mostrando a ambientação fora do galinheiro pela mudança de tonalidade.

A primeira página que abre a história traz a apresentação da personagem. 
$\mathrm{Na}$ entrevista questionamos a existência da minhoca olhando para a Galinha Zinha, visto que a relação desses dois não seria possivel tão facilmente, pois galinhas se alimentam também de minhocas. A resposta dada por Emerson foi bem curiosa, ao afirmar que

[...] na verdade ela tá assim, ela é cumplice tão somente da galinha. Porque a galinha aqui tá super feliz, e como ela é uma galinha que não punha ovos, então ela também seria inofensiva à minhoca se ela passasse por perto. $\mathrm{E}$ aí deduzia só uma cena mais livre mesmo (PONTES, 2017).

Figura 2 - Galinha sem ovo, na boca do povo (2007)

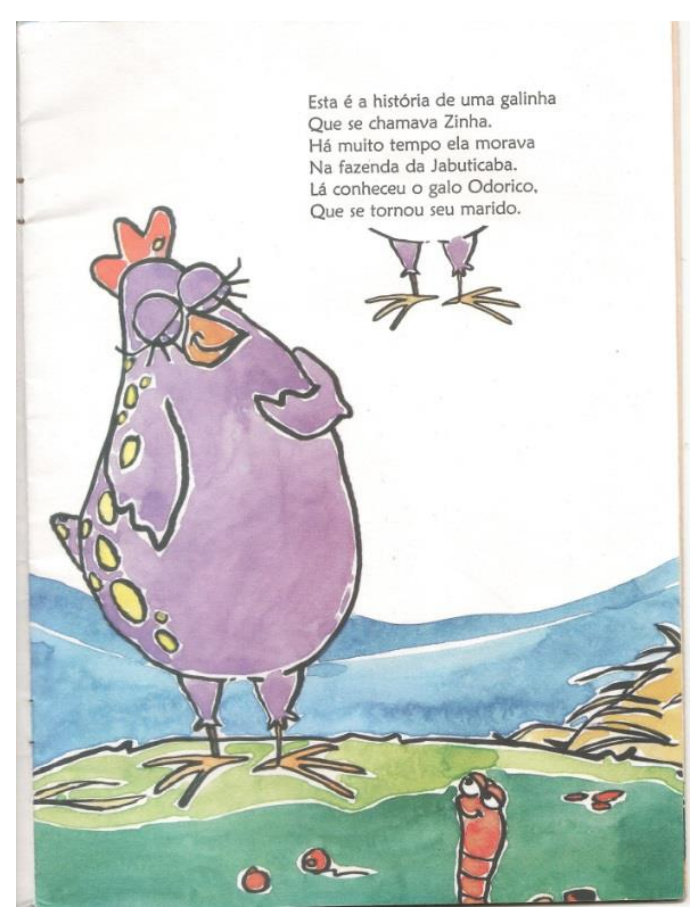

Fonte: Quintas, 2007, p. 3.

Nesta cena, ao fazer esse comparativo de relação entre predador e presa, que no caso existe entre a galinha e a minhoca, deve ser percebida como uma relação cultural, pela qual Barthes afirma que a compreensão de sentido requer, do observador, esse aspecto em especial. Requer em si uma compreensão da relação existente no mundo real e da cadeia alimentar na qual os animais estão inseridos. Logo, a existência da minhoca nessa ilustração constitui um efeito simbólico, que o leitor pode criar inclusive no seu momento de leitura, efetivando um conotativo, que Emerson deixa bastante claro em sua fala.

O ilustrador explica um fato interessante sobre a reprodução gráfica da obra, ao comentar que nela: 
A prancha foi cortada. Não aparece o restinho da minhoca. Ela é tão conotativa à ideia de a galinha criar o pato na história, que aí eu acho que eu podia justamente brincar com isso, de trazer outros personagens à tona que só somasse a ideia da cena. $\mathrm{E}$ aí eu vou só deixar aqui a minhoca olhando pra ela enquanto ela se acha aí garbosa, feliz da vida, mesmo sem saber que ainda não colocava ovos (PONTES, 2017).

Com a declaração de Emerson em relação ao corte da prancha, ele demonstra que partes do processo de publicação da obra não têm influência somente do ilustrador, em relação ao produto, mas também de todo o processo gráfico que desempenha sua função juntamente no produto final, podendo o ilustrador estar envolvido ou não nesse conjunto de ações. No decorrer da obra, isso se repete mais algumas vezes; há exclusão, ou o surgimento de elementos nas páginas, pelos quais o ilustrador não foi o responsável. Assim, a interação entre de texto e imagem, neste caso, constitui uma relação de ancoragem, pois o texto descreve e prende o sentido da imagem. Enquanto a imagem apresenta somente a Galinha Zinha.

A figura a seguir, narra o episódio de Zinha sendo examinada pelo veterinário que dá o diagnóstico de que ela, possivelmente, está doente e deve ir para a panela.

Figura 3 - Galinha sem ovo, na boca do povo (2007)

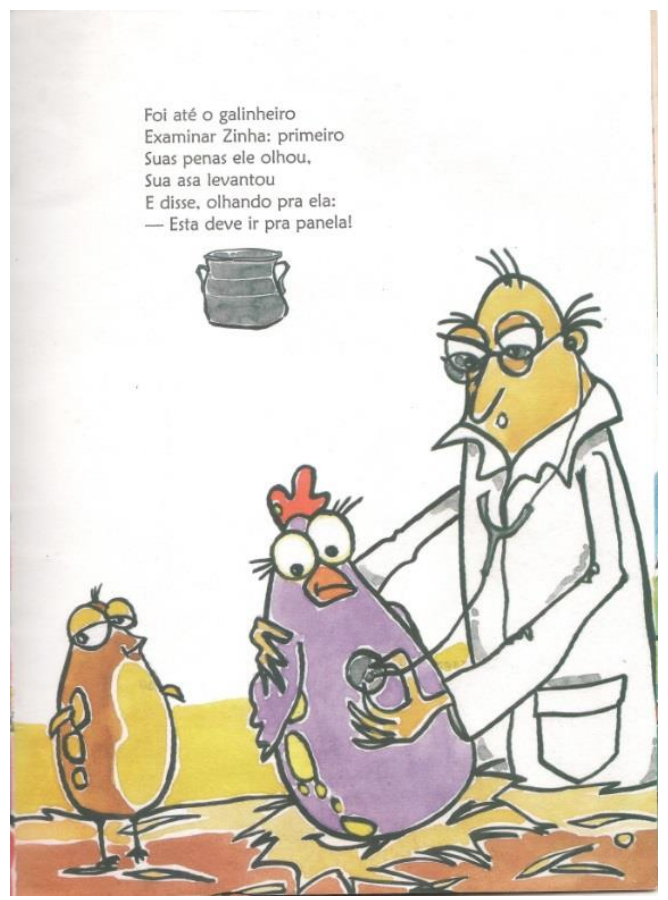

Fonte: Quintas, 2007, p. 9. 
O elemento da panela aparece na parte escrita representada também por meio de desenho logo abaixo. Em conversa com Emerson sobre isso, ele declara que tanto na primeira página, em que há o texto com as pernas da Zinha, há esse segundo momento da repetição da panela em signos distintos, como apenas uma chamamento do que poderá acontecer a galinha, pois a imagem completa da panela em primeiro plano está na página seguinte. Esse elemento foi introduzido na narrativa pelos diagramadores e não pelo ilustrador, para enfatizar a situação. Quanto a esse processo, o ilustrador relevou não gostar desse tipo de inserção, mas que isso foge ao seu controle, posto que o ilustrador entrega a versão final das imagens, e ainda há um processo de elaboração do projeto gráfico, que insere outros sujeitos na produção da obra, responsáveis pela adaptação das imagens da forma que acham mais adequada. Isso revela que o processo de elaboração da uma obra literária infantil ilustrada circunscreve um processo dinâmico de autoria coletiva.

A figura 4, a seguir, narra o momento de transição da fuga da galinha, que é marcada pelo verde da grama e pelo azul do céu, fato que não aparece nas cenas dentro do galinheiro. Ao ser questionado sobre isso, Emerson respondeu que "o galinheiro é muito quente, muito cheio de ocres e de amarelos, até essa coisa da palha, do aconchego. Referência até do calor mesmo, não calor de calor humano, calor animal" (PONTES, 2017). Sobre a cena da fuga ele revelou que "por que tão somente, eu só dou a ideia singular de que ela tá fugindo pra não cair na panela" (PONTES, 2017). E a panela, na organização feita na ilustração, encontra-se logo abaixo da galinha no seu momento de fuga, o que cria uma situação conotativa de nível simbólico. 
Figura 2 - Galinha sem ovo, na boca do povo (2007)

Fonte:

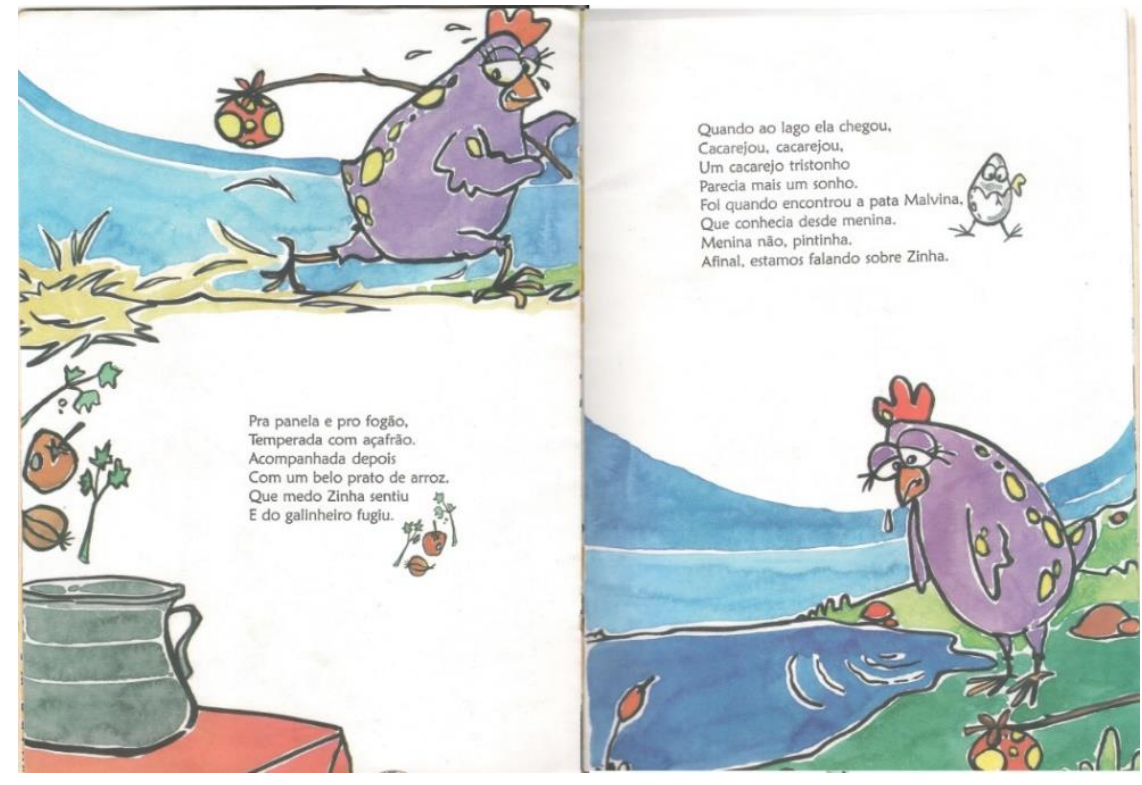

2007, p. 10-11.

Quintas,

No momento da saída de Zinha do galinheiro, ela vai para um lugar em que o céu aparece, o verde fica bem exposto. Em relação a isso, o azul e o verde remetem ao céu e a grama, representando iconicamente dentro do signo imagético o que há por trás das cores. Sobre isso, Emerson explicou que nessa obra:

a paleta é uma paleta fria, que sugere essa coisa do pensar e aí é um momento que ela vai mudando de intelecto mesmo. Ela antes tinha a doença, mas era uma galinha feliz, mas a partir do momento que ela descobre, tudo vai ficando mais sombrio, vai ficando mais triste. Então aí eu vou jogando essa paleta de cor fria pra tratar desse momento que é um momento de tristeza (PONTES, 2017).

Ao ser questionando, se em seu trabalho procurava, então, materializar questões psicológicas e sentimentais dos personagens por meio das cores e do cenário, o ilustrador afirmou que tem isso como predicado, isto é,

pegar a característica de um personagem que é emotivo e jogar ele num ambiente que favoreça isso. Então acho que a tristeza, a coisa da introspecção mesmo que a galinha apresenta aí. Então aí eu acho que dá para ser um cenário mais sóbrio, que não seja de cores tão abertas. Você vê que eu nem uso o amarelo. Só uso aqui e nas pintinhas dela. Pra mostrar essa característica mesmo, eu acho que funciona. [...] não sei se... eu não veria uma galinha triste num dia claro, talvez com o sol ali, e refletindo a face dela... Acho que talvez essa coisa de ter uma paleta mais contida, mais fria mesmo... valesse mais a pena pra mim. O texto não fala de choro, só fala do cacarejo tristonho. Aí 
eu termino, até pra demonstrar mais essa tristeza, eu deixo cair ali a lágrima e ainda brinco aqui de tremular o riachinho (PONTES, 2017).

As duas imagens permanecem no contexto de ancoragem, no qual a imagem sempre está em concordância com o texto. Desta forma, a primeira imagem demonstra a saída de Zinha do galinheiro, em que a passagem desse momento é transmitida de forma simples, quase imperceptível, entre a mudança do galinheiro para o novo mundo no qual ela está prestes a entrar. Emerson criou ali uma situação icônica por ela estar com as 'malas prontas' para fugir, isso é perceptível por que ele se preocupou em fazer o jogo simbólico, que a faz fugir da panela. Na primeira imagem, o olhar de Zinha demonstra essa fuga, pois ela está olhando diretamente para a panela que está logo abaixo.

A última imagem mostra Zinha agora com seu filhote de pato e a junção dos dois ambientes, tanto o mundo lá de fora, como o tom marrom da terra do galinheiro. Este momento representa a junção dos dois ambientes pelo simples contexto de que agora há um pato adotado por galinhas, ou seja, animais de especies diferentes. Criando um pequeno conflito, não negativo, entretanto, no sentido de representar que algumas galinhas não põem ovos para que nasçam patos em lugar de pintos. Criando um sentido conotativo de que mãe é quem choca, quem cria, e não somente quem põe, quem pare. Sobre o tema, Emerson deu sua opinião que é muito certa em relação a este fato: "E aí o livro nem dá chance de você pensar em discriminação, em essa coisa da aceitação, o livro não dá essa chance, ele aceita do jeito que é. E pra fechar justamente a imagem da família feliz" (PONTES, 2017). Toda a imagem serve desse modo para ancorar um sentido da palavra diferente, que aparece no texto escrito, apesar de ela ter várias acepções, bem como a imagem poder constituir outras relações de sentido.

Figura 3 - Galinha sem ovo, na boca do povo (2007) 


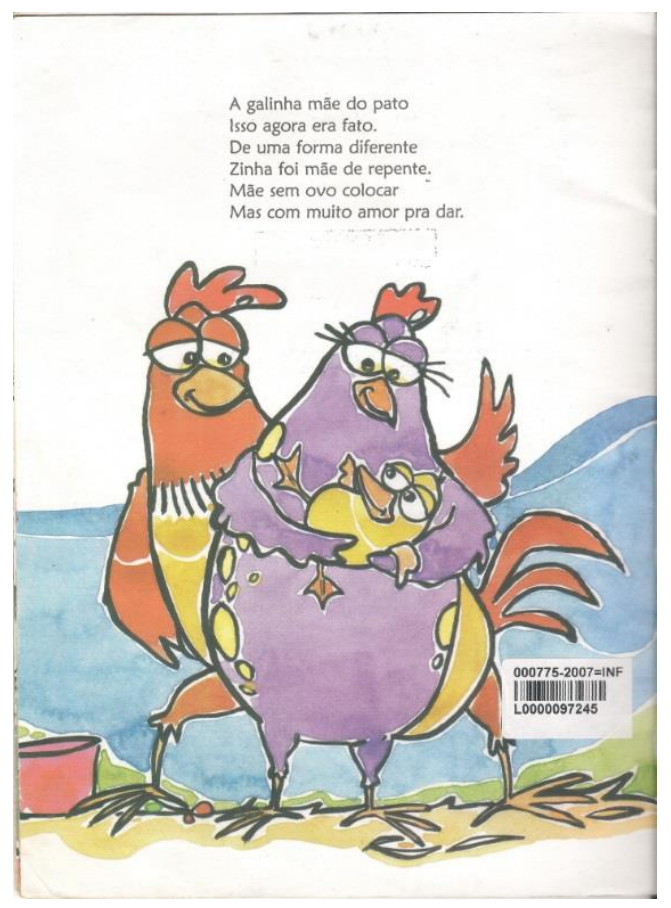

Fonte: Quintas, 2007, p. 16.

Toda a obra de Emerson é permeada pelo conceito de ancoragem, em que a ilustração está sempre fixando o sentido do texto. Suas imagens cumprem a função de ilustrar o que o texto diz, o projeto enunciativo do autor, não se preocupando com o emprego de figuras de linguagem. Porém, nas imagens escolhidas, há sim alguns elementos que aludem ao jogo simbólico, possibilitando a compreensão de outros significados. Porém, ele mesmo afirma em entrevista em relação ao uso de metáforas que não se trata de
um ambiente que eu não me sinto muito seguro. Essa coisa de fazer o espectador pensar, o leitor pensar... eu prefiro ser mais direto mesmo e deixar a imagem por si só, que ela complemente, que ela seduza pelo que ela é. Talvez muito mais pelo traço, pela vivacidade, pela expressão fisionômica do personagem do que deixar uma imagem que sugira, que maquie o texto e passe outra ideia (PONTES, 2017).

Para ele, na ilustração dessa história, acabou por empregar simbolismos que foram apontados por nossa leitura, que ele mesmo não tinha pensado, a profissão de ilustrador desenvolve uma atividade cognitiva que deve ser trabalhada com muita atenção, assim como é a atividade de escrever e de ler requer atenção e didatismo para ser desenvolvido, o que gera sempre um processo dialógico de constituição de sentidos que envolve o ilustrador, o autor e também o leitor.

Nas ilustrações de Rosinha, encontramos outros processos criativos que 
evidenciam a relação do texto com a imagem dentro do processo de autoria. Rosinha, é nascida no Recife, contudo reside em Olinda e já ilustrou mais de 100 livros. Ela agora tanto ilustra para outros autores como também ilustra suas próprias histórias. Sua primeira obra foi o livro: Som Coração (1994), uma coletânea de canções ensinadas na época em que seus filhos eram pequenos. Segundo ela, num ímpeto produziu a obra, posto que seus filhos queriam que a mãe cantasse as mesmas canções da escola, que ela desconhecia, e isso a levou a preparar as imagens com as letrinhas das canções infantis. E assim começou sua história.

A obra que escolhemos dessa ilustradora para a continuidade de nossa análise é "A casa Rosa", escrita por Silvana Pinheiro Taets, publicada em 2004 pela editora: DCL, da cidade de São Paulo com ilustrações de Rosinha. Rosinha não se define quando se trata de técnica, ela se diz uma pessoa que gosta de aprender e isso a leva a criar livros com os mais variados tipos de materiais que vão desde tecido com lápis de cor e tinta acrílica, papel e tinta acrílica, como as histórias contadas somente em tecido, sendo estes apenas bordados, como até o próprio bordado em pedraria.

A técnica empregada neste livro é tinta acrílica sobre uma base. Como a própria ilustradora define: "Acrílico, sobre papel. E papel higiênico que é uma forma de fazer textura" (ROSINHA, 2017).

Figura 4 - Imagem de capa do livro: A Casa Rosa (2004)

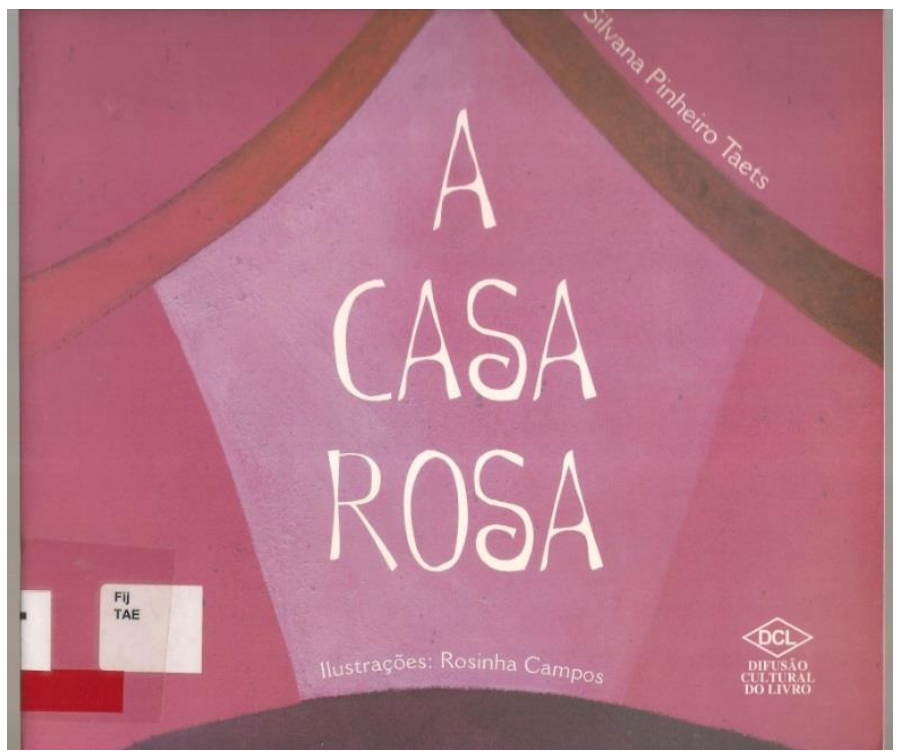

Fonte: Taets, 2004. 
A capa do livro apresenta uma casa cor de rosa, porém nos mostra também que todo o universo que a rodeia é igualmente rosa, fato que comprovamos no virar das páginas. Ao ser questionada sobre a obra, se era rosa por causa da influência até mesmo do nome da ilustradora, Rosinha foi categórica e disse que "não. Que era por conta da história ser sobre a casa rosa mesmo" (ROSINHA, 2017). Percebe-se então a ancoragem dando fixação ao que se encontra no texto juntamente com a imagem, não demonstrando até o momento elementos que aludem o simbólico. Inclusive não se trata de uma obra para meninas, é uma obra para crianças em que o rosa estabelece relações com o título.

Figura 5 - A Casa Rosa (2004)

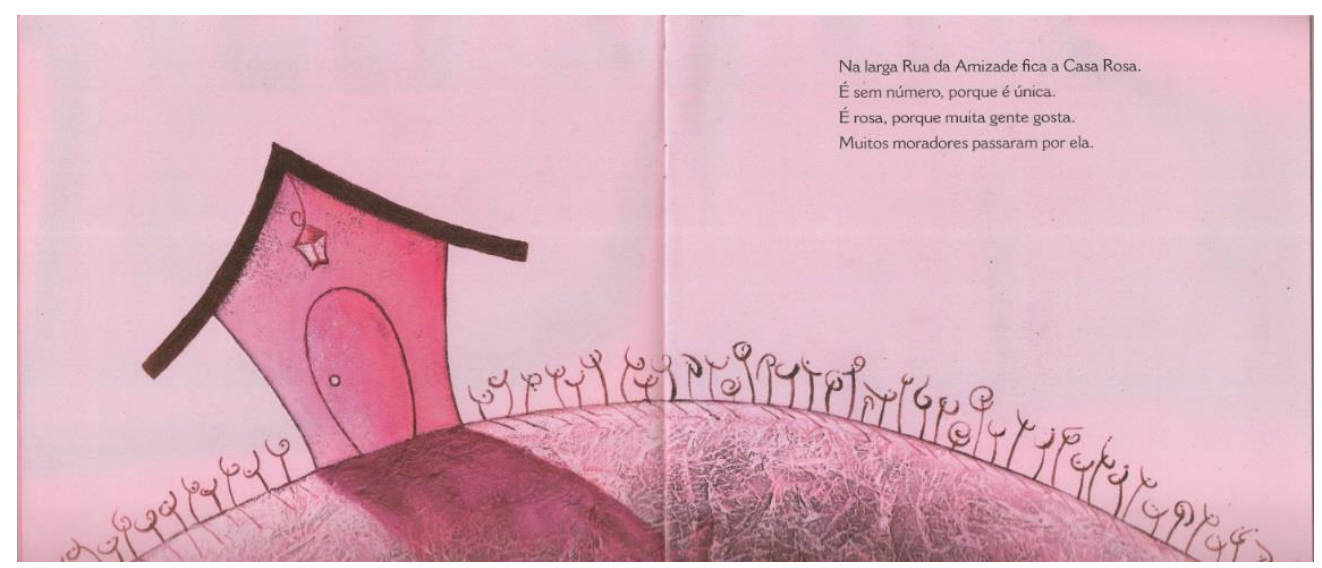

Fonte: Taets, 2004, p. 4-5.

Ao começar a leitura do livro, vemos a casa rosa, com todo o ambiente também rosa e flores por todo o contorno da terra. As ilustrações desse livro devem ser olhadas de uma ponta à outra, sem interrupções. As flores que marcam esse início de livro fazem menção a alguns botões de flor, que podem vir a ser rosas também, assim como a casa, podem florescer. As expressões que este livro carrega são muito sutis, e é preciso de atenção para poder observar as pequenas nuances que ele possui. Ao questionar a ilustradora sobre as flores, ela respondeu "que são apenas flores mesmo" (ROSINHA, 2017). A imagem aqui ancora-se ao texto, no momento de apresentação da casa pelo texto.

Figura 6 - A Casa Rosa (2004) 


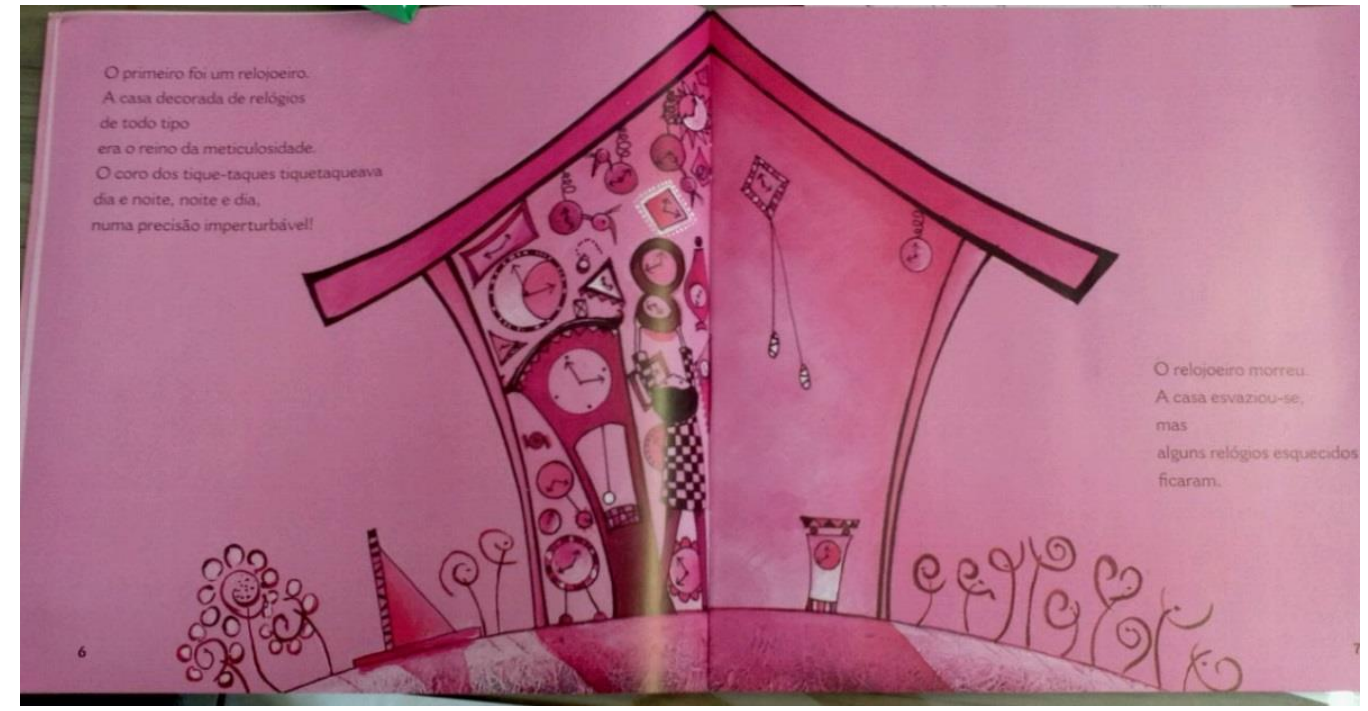

Fonte: Taets, 2004, p. 4-5.

O primeiro morador da casa foi o Relojoeiro, que encheu a casa de relógios. Inclusive há, na ilustração, um relógio de sol que fica ao lado da casa. A representação desse relógio ao leitor que não tem familiridade com esse objeto passa despercebida. Ele funciona como um ícone de um barco, a primeira vista. Em nosso processo de leitura, só constatamos se tratar desse objeto, relógio de sol, a partir da explicação da ilustradora. A relação de tempo também é marcada, além dos relógios, pelo crescimento e desabrochar das flores fora da casa, como se vê na imagem.

Rosinha construiu a ilustração dessa obra para ser lida de ponta-a-ponta, e nota-se que a imagem é muito mais figurativa do que o texto em suas proporções. Ao observarmos essa parte da narrativa, percebemos que o personagem do relojoeiro e os demais que aparecerão, sempre se localizam na página esquerda, na qual o texto relata que um novo morador reside na casa rosa. Enquanto na página direita, quando enuncia a partida dos moradores, sempre é vazia de personagens humanos e só contém alguns pertences deixados pelos dos moradores. Todo o decorrer da narrativa se dá dessa forma. Essa situação pode ser analisada de forma bipartida. Enquanto de um lado há ancoragem da imagem com o texto, no lado oposto é criada uma situação simbólica, que exige do observador um olhar apurado para todos os seus signos, possibilitando aí o aparecimento de sentidos conotativos para a cena.

O texto da página direita pode criar uma pequena confusão, pelo fato de 
a imagem ser vista de ponta a ponta, no entanto, a divisória de páginas exerce papel fundamento na marcação do movimento dos moradores e do tempo. Pode se afirmar que apenas os elementos materializados no canto direito exercem função de relais em relação ao total da imagem, posto que os sentidos criados a partir da relação de representação dos objetos deixados por ser feita com liberdade pelo leitor, de modo simbólico.

Figura 7 - A Casa Rosa (2004)

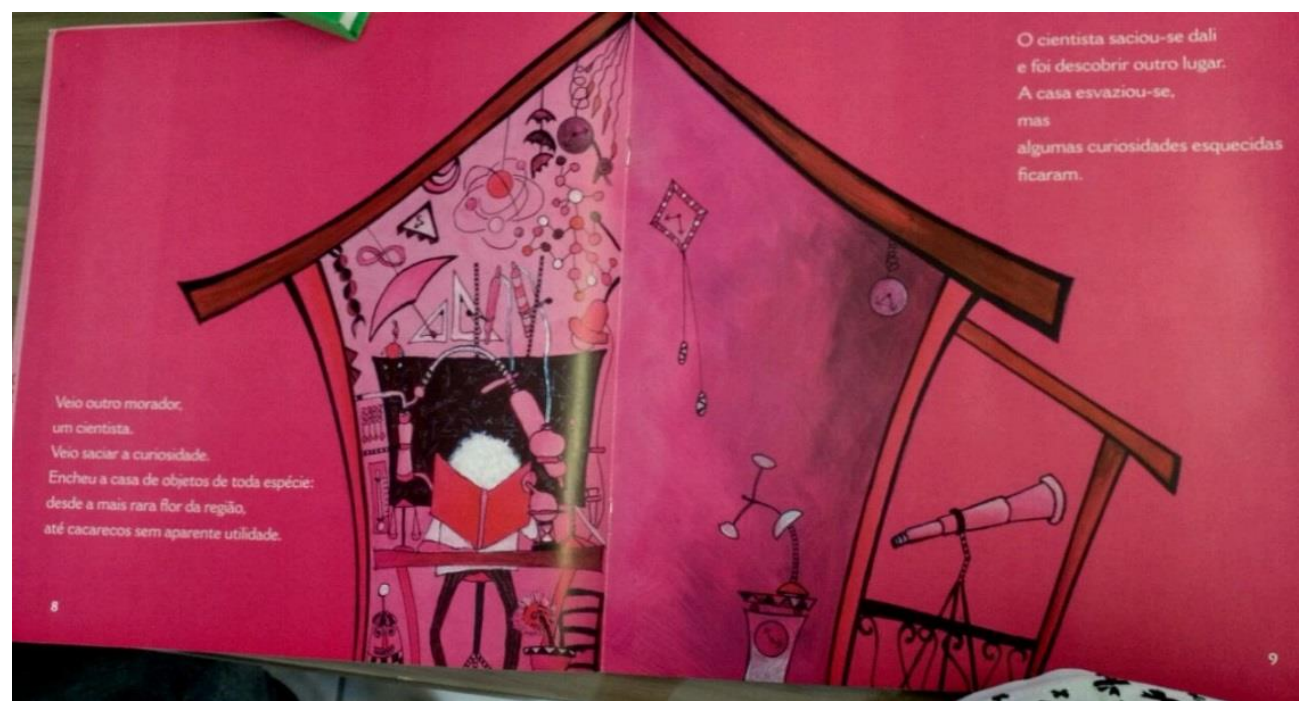

Fonte: Taets, 2004, p. 8-9.

Com a chegada do morador seguinte, o Cientista, pode-se perceber a casa mudando de aspecto. Foi acrescentado, ao lado da casa, uma varanda, e nessa varanda uma luneta. Provavelmente, o Cientista gostava de observar os astros cósmicos, posto que o objeto está apontado para o céu. A luneta torna-se um objeto simbólico que evidencia a esfera que compõe a profissão do personagem: a ciência.

A narrativa relata a descoberta da flor mais rara da região pelo Cientista e que com a saída dele a casa esvasiou-se. Porém, a sequência de imagens e texto evidencia que ele não a levou junto consigo. Porque, visto que era uma das coisas mais raras que ele obtivera em sua andança, ou pesquisa, era de se imaginar que ele a levasse junto. Ao indagar a ilustradora, sobre esse acontecimento, ela se mostrou bastante singular e elucidadora em relação ao ato de ilustrar obras: "Quem deixou a flor não foi o cientista, fui eu! Aqui não diz que ele deixou, diz que ele encheu a casa. Eu que deixei. Por que diz aqui" (ROSINHA, 2017). 
Veio outro morador, um cientista. Veio saciar a curiosidade. Encheu a casa de objetos de toda espécie, desde a mais rara flor da região, até cacarecos sem aparente utilidade. O cientista saciou- se dali e foi descobrir outro lugar." - "A casa esvaziouse, mas algumas curiosidades esquecidas ficaram" Mas ele não diz a curiosidade esquecida. [...] Mas não foi ele que deixou, fui eu que deixei. Eu que decidi, o que é que dele iria ficar. Ele não tá dizendo aqui, por que pra mim é importante, por que ela vai crescer. [E continua]... Agora quem escolheu o que ele deixou fui eu. Como fui eu também que escolhi o que ele trouxe. Como ilustradora! O texto não diz nada disso. O texto não diz que ele tinha um relógio que era um triângulo nem que era um relógio que era um sol, isso foi eu que trouxe e eu que deixei na sala, dentro da casa (ROSINHA, 2017).

Na segunda imagem, em que aparece o Cientista, repete-se o acontecido da primeira imagem. Ao lado esquerdo, o texto ancora a imagem, mas à direita, ocorre novamente, visto que o texto diz que ele parte, mas a página esquerda 0 mostra ali. Criando assim, uma situação ambígua. Logo, na página direita ocorre novamente a função de relais, uma vez que o texto diz uma coisa, e a imagem no seu todo traz outros elementos simbólicos que apontam sentidos outros que não estão materializados no texto. Há uma relação muito forte de revezamento em que ambas as linguagens são necessárias para se constituir o sentido da narrativa. A não ser que analisemos a imagem de forma particular. Nesse caso, olharíamos a imagem e veríamos a casa pela metade; assim, olhando apenas a metade, poderíamos ter a função de ancoragem.

Em sequência, o próximo morador a ir à casa, é um Poeta. Lá ele modifica mais uma vez o ambiente. Criando uma água-furtada para observar o céu à noite e as estrelas, uma antena parabólica surge no topo da casa também. E mais uma vez a luneta é modificada de posição, agora apontando para baixo. Podemos imaginar diversas coisas para as quais essa luneta poderia estar apontando. No caso do poeta, que acabou indo embora da casa, para ser feliz com uma moça pela qual se apaixonara, imaginamos que a luneta aponta para baixo para vê-la passar. Tudo é possível, os sentidos aqui estão abertos a todas as possibilidades interativas do leitor. Ao indagarmos sobre isso, Rosinha complementa que ela própria não sabe o motivo pelo qual

ele botou pra baixo. Hoje eu não sei lhe dizer, não. Ele já vê o que ele quer ver, ele já tem o lugar de ver o céu. Ele não precisa mais ver o céu com a luneta. Entendeu? Agora ele vai ver o pequeno, o micro. E ele deixa as palavras (ROSINHA, 2017). 
O poeta trouxe para casa livros de poesia e as palavras escritas em papéis que foram colados nas paredes, por toda o ambiente.

Figura 8 - A Casa Rosa (2004)

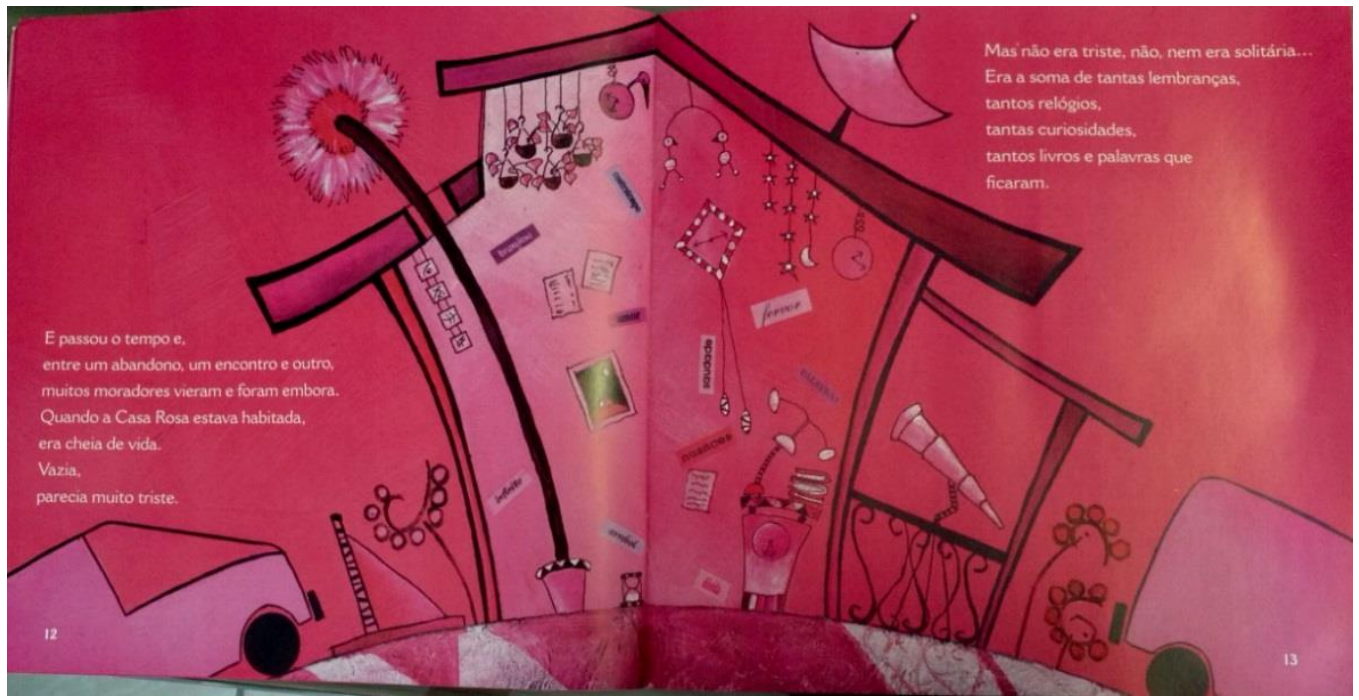

Fonte: Taets, 2004, p. 12-13.

Em continuidade, esse momento do livro é o único em que demonstra que há realmente uma rua, onde há outros moradores, pois aparece a existência de carros passando. Sobre a representação, a ilustradora demonstra que tais elementos servem para representar o movimento: "Na realidade é a chegada e a saída. Tá representando que eles vêm e vão, os moradores vêm e vão da casa" (ROSINHA, 2017). E há, nessa cena, nitidamente ainda a presença da flor rara deixada por Rosinha na casa, agora ela ultrapassa a altura do teto, no qual foi criada uma passagem para que ela também tivesse por onde sair. Essa flor é um dos elementos mais icônicos da história, pois ela também é um dos elementos de transição do tempo e acompanha a passagem dos moradores. Sobre isso a própria Rosinha explica:

Sim, ela vai marcar o tempo, ela vai marcar a passagem do tempo, exatamente. Porque quando ele [o cientista] chegou, ela era pequenininha, aqui o tempo passou e ela cresceu. $E$ junto com ela a casa também cresceu e ganhou outros elementos. $E$ as flores ao redor da casa também desabrocharam (ROSINHA, 2017).

Essa é a última imagem do livro, em que há a representação da chegada e saída dos moradores, demonstrada pelos carros na rua. Aqui a imagem é ancorada pelo texto, pois a artista representou tudo o que está escrito. A casa vazia, porém 
com os antigos pertences de cada morador, juntamente com a flor que ficou alí, que marca o tempo da narrativa, trazendo noção de tempo para o leitor.

Percebe-se, em toda obra de Rosinha, uma liberdade dos sentidos que são criados por elementos da ilustração que ficam livres para o leitor interpretar. Poucos momentos a ilustradora se serve da aconragem do texto para produzir suas imagens e esse processo recobre a narrativa de metáforas e figuras de linguagem que exige certa experiência do leitor. Portanto, o livro toma uma dimensão que ultrapassa a classificação de literatura infantil, ele constitui muito mais sentido conotativo para um leitor adulto por requeres relações dialógicas para constituição dos sentidos dos textos e das imagens.

Logo, para o livro infantil, toda a imagem é significante, podendo conter ou não um significado simbólico. Vai depender muito do estilo do ilustrador, do seu projeto enunciativo em relação ao texto do autor e da sua liberdade de criação dentro da obra. Como já citado, ilustrar é uma atividade cognitiva muito delicada que requer do ilustrador um olhar aguçado e maturidade naquilo que faz, visto que, se ele optar por trazer para sua obra, uma linguagem voltada ao simbólico, ou seja, metafórico, é preciso tomar várias decisões para que o sentido possa ser constituito pelo leitor ou somente pelo autor e ilustrador. Neste sentido, na relação texto e imagem, na ilustração de obras de literatura infantil, tem-se sempre um processo dialógico de constituição dos sentidos, seja pela relação de ancoragem ou de relais, e a tal aspecto o mediador de leitura deve atentar-se.

\section{ALGUMAS (IN)CONCLUSÕES}

A partir disso, considera-se que a profissão de ilustrador para livros infantis é de grande importância no processo de autoria de obras voltadas a esse público, pois se trata de um gênero literário gráfico que deve ser elaborado com o máximo de atenção, pelo fato de que a criança, em seu processo de formação, cognitivo e de personalidade, tem maior capacidade de absorver o conteúdo ali descrito. Para os entrevistados, não existe um filtro que determine o que é correto e errado, cabe à participação ativa de um adulto que o auxilie nesse processo de absorção de conhecimentos, na mediação de leitura, que trabalhará os sentidos presentes na relação texto e imagem. 
Destarte, a imagem deve ser apresentada como forma de comunicação entre o texto e o seu leitor, dispensando a ideia de que ela é apenas um ornamento para embelezar o livro. A imagem é mais que isso, ela é narrativa, ela tem ponto de vista, ela tem voz, ela compõe a linguagem que lhe dá sentido enquanto narrativa.

Em se tratando da análise das obras de Emerson Pontes e Rosinha, a aplicação do pensamento de Roland Barthes, relais e ancoragem, foi de suma importância, e podemos perceber o quanto existe de distinção na forma entre 0 trabalho dos dois ilustradores, um que se preocupa mais com a fixação dos sentidos entre a imagem e do texto e o outro com o revezamento. Ambas histórias e imagens possuem qualidades e seus processos de criação de ilustrações delimitam as faixas etárias a que serão destinadas, a obra de Emerson destina-se a um público em idades iniciais de aprendizado na leitura, tanto da parte escrita como da imagética, enquanto que a obra ilustrada por Rosinha requer, do leitor, um olhar mais atencioso e cauteloso para os signos materializados, visto que é necessário o acompanhamento de um adulto para auxiliar na leitura e compreensão da obra.

Logo, a relação do texto e imagem se dá em pelo menos três formas: o tipo de imagem que é empregada nos livros; o projeto gráfico que é utilizado para a confecção da parte física do livro; e o tipo de figura linguística, dentro da imagem, que será empregada em consonância ou não com a parte textual. No processo de ilustração imagem e texto, tecem relações diretas na constituição dos sentidos e configuram um processo de autoria dialógico entre o autor, 0 ilustrador e o leitor.

\section{REFERÊNCIAS}

ALBERTON, Maria Luiza de Souza. A apropriação das ilustrações de livros de literatura infantil: uma experiência de alfabetização estético-visual das crianças. 2010. Trabalho de Conclusão de Curso (Licenciatura em Artes Visuais) - Universidade do extremo Sul Catarinense, Criciúma, 2010.

ALMEIDA JUNIOR, Licinio Nascimento. Conjecturas para uma retórica do design [gráfico]. 2009. Tese (Doutorado em Artes e Design) - Pontifícia Universidade Católica do Rio de Janeiro, Rio de Janeiro, 2009. 
AZEVEDO, Ricardo. Texto e imagem: diálogos e linguagens dentro do livro. In: SERRA, Elizabeth D'angelo (org.). 30 anos de literatura para criancas e jovens: Algumas leituras. Campinas: Mercado de Letras, 1998. p. 1-7.

BARTHES, Roland. A câmara clara. Nota sobre a fotografia. Rio de Janeiro: Nova Fronteira, 1984.

BARTHES, Roland. A retórica da imagem. In: BARTHES, Roland. O óbvio e o obtuso. Rio de Janeiro: Nova Fronteira, 1990. p. 27-43.

CONTRERA, Malena Segura; HATTORI, Osvaldo Takaoki. Publicidade e Cia. São Paulo: Thompson, 2003.

CUNHA, Angélica Furtado da; COSTA, Marcos Antonio; MARTELOTTA, Mário Eduardo. Linguística. In: MARTELOTTA, Mário Eduardo. Manual de linguística. São Paulo: Contexto, 2008. p. 15-30.

FONSECA, Lêda Maria da. Leitura de imagens e a formação de leitores. Caderno de Pesquisa, São Paulo, v. 36, n. 128, p.451-472, maio 2006. Trimestral.

JOLY, Martine. Introdução à análise da imagem. 12. ed. Campinas: Papirus, 2003. (Coleção Ofício de Arte e Forma).

MARTELOTTA, Mario Eduardo (org.). Funções da linguagem. In: MARTELLOTA, Mario Eduardo et al. Manual de linguistica. São Paulo: Contexto, 2008. p. 31-36.

MARTINS, Wilson. A palavra escrita: história do livro, da imprensa e da biblioteca. 3. ed. São Paulo: Ática, 2002. 519 p. (Temas).

PONTES, Emmerson. A ilustração da obra Galinha sem ovo na boca do povo: depoimento. Recife, 2017. Entrevista concedida a Rayanne Ferreira Alves Barbosa de Lima.

QUINTAS, Cristiane. Galinha sem ovo na boca do povo. Recife: Prazer de Ler, 2007. 18 p. Ilustração de Emerson Pontes.

RAMOS, Graça. A imagem nos livros infantis: caminhos para ler o texto visual. Belo Horizonte: Autêntica Editora, 2013.

ROSINHA. A ilustração da obra A casa rosa: depoimento. Olinda, 2017. Entrevista concedida a Rayanne Ferreira Alves Barbosa de Lima.

SPENGLER, Oswald. La decadencia de ocidente: bosquejo de uma morfologia de La historia universal. Madrid: Espasa Calpe, 1952.

TAETS, Silvana Pinheiro. A casa rosa. São Paulo: Dcl, 2004. 16 p. Ilustração de Rosinha. 
VOLOCHÍNOV, Valentin Nikolaevich. A Construção da Enunciação e Outros

Ensaios. São Carlos: Pedro \& João Editores, 2013. 273 p.

ZIMMERMANN, A., RAMALHO e OLIVEIRA, S. R. E. Ilustrações de livros infantis no ensino de artes. In: XVI Encontro da Associação Nacional de Pesquisadores em Artes Plásticas, 2007. I Congresso Educação, Arte e Cultura, 2007.

ZIMMERMANN, Anelise. As ilustrações de livros infantis: o ilustrador, a criança e a cultura. 2008. 148 p. Dissertação (Mestrado em Artes Visuais) Programa de Pós-Graduação em Artes Visuais, CEART/UDESC. Florianópolis, 2008.

\title{
UNDERSTANDING ILLUSTRATION IN CHILDREN'S LITERATURE BASED ON ROLAND BARTHES'S THOUGHT
}

\begin{abstract}
Introduction: Children's literature has its origins in oral myths, fables and fairy tales, and illustration accompanies them from birth as a literary genre. It is required that librarians do not restrict their action only to assuring access of books with images and texts to be read by children, but also to become familiar with the process of constitution and the relations between image and text in the universe of narratives by the illustrator and the author, in order to better mediate between the literary work and the reader. Objective: Therefore, in this article, we intend to discuss the importance of illustration and the role of illustrators in children's literature, as a way to emphasize the architecture of a dialogue between the languages used in the conjunction of narratives that integrate author, illustrator, work and reader. Methodology: We have collected data through exploratory and documentary bibliographic research, and analyzed them through the concepts of relay and anchorage, by Roland Barthes. Our selection covered works of two illustrators living in the Metropolitan Region of Recife, and we interviewed them. Results: The statements of the illustrators regarding their production have been recorded, and were instrumental to determine how the interaction processes and the constitution of connotative and denotative meanings between the image and the text take place in children's literature works. Conclusions: There are at least three ways the relationship between text and image take place: the type of image that is used in books; the graphic design that is used for the preparation of the physical part of the book; and the type of linguistic figure, within the image, which will be used in line or not with the textual part. It will depend a lot on the style of the illustrator, his enunciative project in relation to the author's text and his freedom of creation within the work.
\end{abstract}

Descriptors: Children's literature. Mediation in the library. Images. Language.

\section{ENTENDER LA ILUSTRACIÓN EN LA LITERATURA INFANTIL DESDE EL PENSAMIENTO DE ROLAND BARTHES}




\section{RESUMEN}

Introducción: La literatura infantil tiene su origen en mitos orales, fábulas y cuentos de hadas, y la ilustración los acompaña desde el nacimiento como género literario. Es necesario que el bibliotecario no limite su acción sólo a la disponibilidad de obras infantiles con imágenes y textos para ser leídos por los niños, sino también a entender el proceso de constitución y las relaciones entre imagen y texto en el universo de las narrativas del ilustrador y del autor, con el fin de desarrollar las mejores prácticas de mediación entre la obra y el lector. Objetivo: Entonces, en este artículo, pretendemos discutir la importancia de la ilustración y el papel del ilustrador en la literatura infantil, como una forma de enfatizar la arquitectura de un diálogo entre los lenguajes utilizados en el conjunto de narrativas que integran autor, ilustrador, obra y lector. Metodología: Se han seleccionado datos a través de la investigación bibliográfica exploratoria y documental, analizada en base a los conceptos de relais y anclaje, por Roland Barthes. Se seleccionaron obras de dos ilustradores que viven en la Región Metropolitana de Recife, así como también se realizaron entrevistas con ellos. Resultados: Se identificaron las declaraciones de los ilustradores en sus obras, y se observó cómo los procesos de interacción y la constitución de significados connotativos y denotativos entre la imagen y el texto tienen lugar en obras de literatura infantil. Conclusiones: La relación entre texto e imagen tiene lugar en al menos tres formas: el tipo de imagen que se utiliza en los libros; el diseño gráfico que se utiliza para la preparación de la parte física del libro; y el tipo de figura linguística, dentro de la imagen, que se utilizará en línea o no con la parte textual. Dependerá mucho del estilo del ilustrador, de su proyecto enunciativo en relación con el texto del autor y de su libertad de creación dentro de la obra.

Descriptores: Literatura infantil. Mediación en la biblioteca. Imágenes. Lenguaje.

Recebido em: 08/11/2019

Aceito em: 23/06/2020 